\title{
Conditions and Problems in the Promotion of Youth's Behaviors in Accordance with the Islamic Way of Life by Muslim Leaders of Ban Sarong, Khao Tum Sub-district, Yarang District, Pattani Province
}

\author{
Kasetchai Laeheem ${ }^{1}$, Dolmananch Baka ${ }^{2}$, Hasbullah Tahe ${ }^{3} \&$ Sasuree Walee $^{3}$ \\ ${ }^{1}$ Faculty of Liberal Arts, Prince of Songkla University, Hatyai, Thailand \\ ${ }^{2}$ Independent scholars, Muang, Pattani, Thailand \\ ${ }^{3}$ Faculty of Liberal Arts and Social Sciences, Yala Islamic University, Yarang, Pattani, Thailand \\ Correspondence: Kasetchai Laeheem, Faculty of Liberal Arts, Prince of Songkla University, Hatyai, Songkhla, \\ Thailand. E-mail: Lkasetchai@yahoo.com
}

Received: April 26, 2013 Accepted: July 2, 2014 Online Published: August 20, 2014

doi:10.5539/ass.v10n17p85 URL: http://dx.doi.org/10.5539/ass.v10n17p85

\begin{abstract}
The purpose of this research was to investigate conditions and problems in promoting youth's behaviors in accordance with the Islamic way of life by Muslim leaders of Ban Sarong, Khao Tum Sub-district, Yarang District, Pattani Province. The data were collected through a knowledge management discussion forum with 10 religious leaders, 10 local leaders, 10 core youth leaders, and 10 parents and guardians. Content analysis was conducted using logical comparisons of concepts, theories, and research reports coupled with contexts. The research findings revealed that Muslim leaders realized, gave importance to, and were determined to promote youth's behaviors in accordance with the Islamic way of life; however, they still lacked knowledge, understanding, skills and experience in promoting youth to have behaviors in accordance with the Islamic way of life. Moreover, it was found that Muslim leaders lacked social relationships with youth while youth did not give importance to, did not realize, and did not pay attention to activities that were to promote behaviors according to the Muslim way of life organized for them by Muslim leaders. As a result, the promotion of behaviors in accordance with the Islamic way of life was not yet successful.
\end{abstract}

Keywords: conditions and problems, promotion of behaviors, behaviors in accordance with the Islamic way of life, youth, Muslim leaders

\section{Introduction}

Muslims have a unique way of life that they must strictly practice according to the religious principles that set a perfect life where beliefs and practice are molded together, and the secular activities and religious activities are in good harmony. These appear in the Koran and are modeled by the prophet Muhammad (Anmunajid, 2004; Laeheem \& Baka, 2010). However, society nowadays has changed very fast along with technological advancements that affect the Muslim way of life both directly and indirectly. For example, parents are busy because of economic conditions which make them have no time to closely teach and train their children. Muslim youth are interested in activities that are presented in the media with the content that is more exciting and fun than religious activities. Muslim leaders neglect social problems that violate religious principles, and such problems are so many that they become normal. As a result, Muslim youth deviate from the correct way of life, give importance to leading their lives wrongly and in conflict with Islamic principles, and rejoice in the modern world so much that they become slaves of modern values. All these have sadly caused worrisome social problems. For example, female youth do not wear head-scarves, and for some of those who wear them, they wear them in such a way to show their beauty. Some youth are addicted to drugs, sexually deviated while others gamble, do not pray and do not fast, etc. (Anmunajid, 2004; Annadwee, 2004). This is in correspondence with a study that found that most Muslim youth in the three southern border provinces lead their lives in violation of Islamic principles. For example, they are in same sex relationship unlimitedly and unduly free. They usually do nonsense activities and make troubles. They openly have friends of the opposite sex, and feel free to hold hands, caress, kiss, and have premarital sexual relations. Moreover, they do not give importance to studying religion, do not spend their free time usefully, turn to all vices, have no job, adapt their clothes to look modern, do not 
practice religion, avoid participation in activities in helping others, and do not participate in community activities (Laeheem \& Baka, 2010). The problem of Muslim youth violating Islamic principles has long become a repeated and chronic problem and cannot be solved alone by anyone individuals or organization but it requires cooperation from all related individuals and organization (Mahama, 2009).

As can be seen, Muslim youth nowadays have more freedom in the changing society with rapid development. The gaps between children and parents are wider not only in their thoughts but also in doing activities together. Parents have to work and to be responsible for the family economy and have no time to socialize their children. Consequently, Muslim youth lead their lives without receiving good advice and correct guidelines according to religious principles. They are after the fashion, influenced by mass media and peers, admire modernity, and spend more time with high technology. It is said that recently Thai Muslim society has changed all the time economically and socially which affects their living condition and way of life (Boonyasith, 1988). Therefore, Muslim leaders who are also directly responsible for how youth live their lives in Muslim society must realize and give important to the problems, and must play a role in training, warning, and encouraging Muslim youth to strictly follow Islamic principles, and in correcting youth's misbehavior (Baka, 2007; Laeheem \& Baka, 2010). Religious leaders must perform their duty in socializing members of society to hold onto good deeds, morals, moral awareness, knowing right from wrong, appropriate behavior, and self-determination in a good way of life. They must also promote Muslim youth to live the Islamic way of life and according to social norms (Boonyasith, 1988). Islamic socialization is development of personality and human character in accordance with Islam so that they have morals and ethics that make them exist peacefully and happily in society (Khagphong, 2004; Mahama, 2009). Muslim leaders must play an important role in solving social problems that are happening and they must be an important driving force in looking after youth because it is their responsibility towards God. According to Muslim beliefs, they will be tested in the next world. Therefore, Muslim leaders must help each other instill awareness in youth that they have to live their lives according to Islamic principles and they must be modeled after the prophet Muhammad. There must be training on Islamic ethics regularly for all youth and promotions for them to study about the religion along with general subjects. The government sector should allow the provincial Islamic committees to have a role to play completely in looking after youth, especially in their misbehavior about having opposite sex friends, improper ways of dressing, doing vices, etc. Islamic laws should be seriously enforced and implemented as the highest and absolute laws such as laws related to how to dress, having opposite sex friendships, and other behaviors that violate Islamic principles (Laeheem \& Baka, 2010).

The abovementioned conditions and problems make it necessary for an investigation into the conditions and problems in promoting youth to have behaviors in accordance with the Islamic way of life by Muslim leaders of Ban Sarong, Khao Tum Sub-district, Yarang District, Pattani Province. The results of this study will be useful for setting guidelines for promoting and supporting Muslim leaders to look after youth according to the Islamic way of life. Moreover, they can be useful in providing assistance for youth who have risk behaviors that are not in accordance with Islamic principles to behave more in the Islamic way before the problem becomes more severe and difficult to solve.

\section{Methods}

In this qualitative study, data were gathered through a knowledge management discussion forum attended by four groups of key informants in Ban Sarong village, Khao Tum Sub-district, Yarang District, Pattani Province. They consisted of 10 religious leaders, representatives of local leaders, 10 core youth leaders, and 10 representatives of parents and guardians. In the preliminary analysis, the data were categorized according to the issues of the objective. Then content analysis was conducted using the logical comparisons of concepts, theories, and research reports coupled with contexts.

\section{Results and Discussion}

From the knowledge management discussion forum and in-depth interviews with Muslim leaders, core youth leaders, parents and guardians, and academics to investigate the conditions and problems in promoting youth to have behaviors in accordance with the Islamic way by Muslim leaders of Khao Tum Sub-district, Yarang District, Pattani Province, the following interesting findings were revealed.

1. Muslim leaders realized, gave importance, and were determined to promote youth to behave in accordance with the Islamic way. They thought that this was the responsibility assigned to them by Allah to look after, instill, and promote youth to behave and live the way of life according to the Islamic principles. Mr. Abdulla (a youth leader) said, "...Muslim leaders gives importance and understand their role in looking after youth the Islamic way which is their responsibility both in this world and the next world...” Mr. Eliyas (a Muslim leader) said, “...Muslim leaders see and realize the importance of looking after youth according to the Islamic way and 
expectation of the community and society. They make efforts in seeking cooperation from individuals and they play their role without thinking that it is the duty of other individuals or organizations..." Mr. Ibrohem (a guardian) said, "...Muslim leaders must do their duty of training youth on Islamic ethics and give them knowledge and understanding of Islamic principles so that youth can live the correct Islamic way of life..." In addition, Muslim leaders have established a work team, distributed responsibilities to team members, and clearly set the types of activity in looking after and promoting the Islamic way of behavior for youth. This can be seen from Mr. Baharun who said, "...Muslim leaders have set a committee especially for looking after youth, set the work structure, and organized activities related to religious principles that can develop youth's potential..." Miss Robiyah (a guardian) said, “...Muslim leaders promote and look after young Muslim women by setting up vocational groups for earning extra money, doing activities to help society, and doing study group activities..." Miss Solihah (a core youth leader) emphasized, "...Muslim leaders have clear ways for looking after youth according to their work structure in order for youth to practice according to the Islamic principles, and for giving warnings to youth who do not practice accordingly..." Thus, it is obvious that Muslim leaders of Ban Sarong give importance to looking after youth and consider that it is their duty or commitment to practice according to the work structure that is assigned to them to do in accordance with the Islamic principles. It is their responsibility to look after people in the community, set rules for the community, train, teach and socialize youth to behave the Islamic way. This is in agreement with the results of a study that revealed that Muslim leaders play a very important role in providing assistance, care, and promotion for Muslim youth to behave the Islamic way a live a correct Islamic way of life. This can be done by setting up youth clubs or youth groups to make most Muslim youth live the Islamic way life (Laeheem, 2012). Religious leaders are responsible for training, teaching and socializing youth according to the Islamic principles to make them behave correctly and properly with morals and ethics (Boonyasith, 1988; Suphap, 2003). Community leaders participate in child and youth development regarding their health and prevention, intelligence and competence in working, emotion and responsibility according to their age, and participation in the community and society. Furthermore, Muslim leaders must help instill in Muslim youth awareness in living the Islamic way of life and being modeled after the prophet Muhammad (Laeheem \& Baka, 2010).

In addition, it can be seen that Muslim leaders have awareness and realization in looking after and promoting Muslim youth to behave the Islamic way of life by giving them knowledge and understanding of principles of belief, practice, moral and ethics because these are people's actions according to their role, responsibility and their given social positions. The reason is for Muslim youth to take as their life system and use it in the daily life correctly according to the principles of belief and principles of Islam as it is said that Muslim leaders are in the status and social position that they must perform the duty assigned to them. They must be knowledgeable in the ordinances, the work under their responsibility, and they must take care that Muslims in the community behave in accordance to Islam (Sengpracha, 1994; Sengpracha, 1998; Suratanakawikul, 1999; Department of Religious Affairs, Ministry of Education, 1999; Satsangan, 2000). Muslim leaders train, teach, refine the mind, nurture intelligence, bodies and soul of Muslim youth by giving them complete and correct Islamic religious education about the principles of belief, practice, moral and ethics that enable Muslim youth to have moral, ethics, discipline, and know how to live happily in society. Such training, teaching, and refining can prevent youth from social problems, make them humble and live their lives in accordance with the Islamic ordinances (Narongraksakhet, 1997; Mahama, 2009; Baka \& Laeheem, 2010). Hence, the Islamic way of looking after and promoting Muslim youth is considered the model or guidelines that Muslim leaders must do as expected by society or as assigned to them according to their role, authority, and social position.

2. Muslim leaders lack knowledge and understanding of the role assigned to them, and they lack skills and experience in promoting youth to behave the Islamic way. Most Muslim leaders do not understand their role as designated by Islam and they do not use Islamic teachings as the main guideline in promoting behaviors that are in accordance with the Islam. As a result, they cannot achieve their work in promoting youth to behave the Islamic way. This can be seen from what Mr. Abdulhaleem (a religious leader) said, “...religious leaders lack correct knowledge and understanding. They don't use the principles from the Al-quran and the Al-hadith so they don't understand their role in which they have to be responsible in this world and the next world. They don't know the existing problems and what they have to do with the problems and how to solve them..." Mr. Muhammad (a representative of the guardians) said, “...Muslim leaders don't have knowledge and understanding about how to promote youth to behave in accordance with the Islamic way, especially in applying religious principles in the present time..." Reflections from two youth representatives are as follows: Mr. Adam said, "...Muslim leaders lack knowledge and understanding, and neglect their role in promoting youth to behave according to the Islamic way of life...” while Mrs. Robiyah said, “...Muslim leaders don't understand their role, and don't have knowledge in youth development so the community has problems..." Additionally, Muslim 
leaders lack skills and experience in promotion of the Islamic way of behaviors among youth because most Muslim leaders do not have opportunity to develop their skills and experience through participation in seminars or study visits. This can be seen from what Mr. Ahamad (a religious leader) said, “...Developing youth's behaviors requires knowledge, skills and experience, so leaders need training and seminars conducted by speakers from either the government or private sector to help increase their knowledge and skills in youth development. Study visits to other places should be organized for Muslim leaders to exchange opinions and experience with other organizations that have been successful in youth development..."

As can be seen, Muslim leaders lack knowledge and understanding of the role assigned to them according to the Islamic principles. This is one of the important factors affecting the work in promotion of youth behaviors the Islamic way. A lack of guidelines or proper methods is a problem for leaders to perform their duty as expected or designated by society. Thus, it is necessary for leaders to study and seek knowledge about their role to truly understand it (Sengpracha, 1994; Sengpracha, 1998; Satsangan, 2000). Muslim leaders must study to obtain knowledge and understanding of the principles of belief, practice, and moral and ethics and take them as the system of life so that they have prosperity in their knowledge, skills, process, and good attitudes continually, and so that they can correctly apply them in the work under their responsibility (Mahama, 2009). They should take it as the system of life and use it as guidelines for promoting Muslims to exist in society happily and peacefully. This is the complete process of socializing and nurturing the mind (Narongraksakhet, 1997). Leaders must also have profound knowledge of the mandates and work under their administration because leaders who lack knowledge can become a puppet on a string and can eventually lead society to disaster (Department of Religious Affairs, Ministry of Education, 1999). Moreover, learning about Islam can make Muslims humble, live a life according to the Islamic principles, and prevent learners from problems, especially those problems related to the social environment and change (Baka \& Laeheem, 2010).

3. Muslim leaders lack social relations with youth. Making friends or positive relationships with Muslim youth by supporting and helping, maintaining and developing with youth can contribute to promotion of youth's behaviors the Islamic way with good cooperation. However, Muslim leaders in Ban Sarong do not interact nor have good relationships with youth because of the generation gap and the leaders do not try to find opportunity to be familiar with youth. As a result, youth do not accept them and activities promoting youth to behave the Islamic way cannot access the target group of youth. This can be seen in what Mr. Anwar (a youth leader) said, “...Muslim leaders do not really listen to youth and do not meet youth's need and this leads to resistance among youth who naturally do not accept the leaders. Muslim leaders are not aware and do not understand the reason why youth behave the way they do, instead they think that youth have bad behaviors. So the relationship gap between Muslim leaders and youth gradually widens...” Mr. Usman (a youth leader) said, “...Muslim leaders lack connection with youth and are not open-minded enough for participation in activities they organize. They don't try to find opportunity to get acquaintance with youth. So, they don't receive cooperation from youth, and some youth participate unwillingly..."

Thus, the lack of social relations with youth has made Muslim leaders unable to correctly perceive needs and attitudes of youth, and as a result, youth do not cooperate in activities that are organized by Muslim leaders, and that are meant to promote youth to behave in the Islamic way. This corresponds with study results that Muslim leaders need to have good and effective social relations with youth, and Muslim leaders should make efforts to make friends with youth and make them feel that Muslim leaders are good friends, respectable older brothers and fathers. This is one important factor that can make looking after youth the Islamic way a success, and attract good cooperation from youth to participate in activities that promote the Islamic way of life (Laeheem, 2012; Laeheem, 2013a; Laeheem, 2013b; Laeheem, 2013c; Tahe \& Laeheem, 2013; Laeheem \& Madred, 2014).

4. Muslim youth do not give importance to, do not realize and do not pay attention to activities to promote behaviors the Islamic way that are organized by Muslim leaders. Instilling the principles of belief and practice to Muslim youth requires techniques and method that are attractive and meet the needs of the youth but Muslim leaders in Ban Sarong lack skills, knowledge, and understanding of such techniques and methods. As a result, Muslim youth do not cooperate and are not interested in the promotion of the Islamic way of behavior organized by Muslim leaders. Mr. Ahamad (a Muslim leader) said, “...In promoting the Islamic way of behavior among Muslim youth, it is very necessary for Muslim leaders to have knowledge, understanding, skills, and experience to interest and attract youth to participate in the activities in order to achieve the goal that has been set..." Besides, the activities organized by Muslim leaders do not meet the needs and interest of Muslim youth, so they receive no cooperation from youth in participation in the activities. This is reflected by Mr. Yahya who said, “...Muslim leaders usually organize activities to warn youth in the community to realize and practice the Islamic principles regularly but only a few youth participate because youth usually think that the activities are boring 
and not interesting...” Mr. Usman emphasized that “...During the night, Muslim leaders normally give religious lessons to youth in the community for them to learn religious principles and to be able to practice them correctly. But only 10 - 15 youths are interested in the activities..." Mrs. Salma (a guardian) said, “...Every month, Muslim leaders meet with youth to exchange their views, and during the school breaks, Muslim leaders organize training on ethics for youth. But these two types of activities are not very well accepted as they should have been..." Therefore, it can be seen that activities that are organized to promote behaviors according to the Islamic way at Ban Sarong do not receive cooperation and attention from youth because most of the activities organized by Muslim leaders do not meet the needs and interest of youth. The type and style of the activities remain the same. There are not many types of activities and mainly focus on religious activities without integration of secular and religious activities. The activities should incorporate religious principles into them to make them interesting and meet the needs of youth. Activities that are used to socialize the mind and to instill social norms in youth should include principles of moral and ethics so that youth can learn the value, regulations, and are able to live with others in society (Sengpracha, 1998; Satsangan, 2000; Suphap, 2003).

In addition, most of the activities from the Muslim leaders' concepts lack cooperation from youth and the activities do not promote youth to have opportunity to operate them by themselves so many youths refuse to participate in the activities. Consequently, the goal that has been set cannot be achieved. This is reflected in the statements that specify that promotion of work organized and performed by a group of people who have the same goal that include all people concerned with the clear part of the work under their responsibility can result in a very high opportunity for success (Mapobsuk, 2000; Tansakul, 2004; Spector, 2006). Working in a group of the same interest and needs is considered motivation for work and can help develop the work process to achieve the goal (DeLamater \& Myyers, 2007). Muslim leaders that place emphasis on the process that involve youth in the work is to give opportunity to core youth leaders to take responsibility in looking after and promoting behaviors the Islamic way among youth themselves. Giving opportunities to Muslim youth to freely make decisions and equally at all the stages of activities from the stage of identifying the problems and the causes, to the stages of planning the activities, implementing the plan, monitoring and evaluating the activities is the main factor that can interest youth to voluntarily participate in the activities with enthusiasm and intention. Eventually, this will make the activities successfully achieve the goal (Patanapongsa, 2004; Srimechai, 2004; Bureekul, 2005; Prachantawanich, 2007). Thus, it can be seen that emphasis on the process that includes participation from youth can achieve in youth participation in the activities that interest and meet the needs of youth.

5. The promotion of behaviors in accordance with the Islamic way has not yet been a success. Muslim youth in Ban Sarong are not interested in activities and do not cooperate by participating in activities to promote behaviors that are in accordance with the Islamic way. This has resulted in many Muslim youth (approximately 95 percent of them) do not behave according to the expectation of Islamic society and behave in conflict with the Islamic principles. These behaviors include having same-sex friends freely without limits and usually do nonsense activities, making troubles, having opposite-sex friends openly and hold hands, embrace, kiss and even have premarital sexual relationships. They give more importance to other subjects than the religious subject. They do not know how to spend their free time usefully. They are engaged in all vices, and unemployed. They dress in a modern way like Western movie stars and singers. Their relationships with their family members, relatives, neighbors and community are not very close, and they lack good relationships with each another. They neglect and do not give importance to religious activities. They do not give importance to doing good things for the community and avoid doing it. These can be seen in what Mr. Abdulrohim (a religious leader) said, "...Most youth choose to have same-sex friends who have the same concepts and ideologies and they go out wasting their time. For most youth who have opposite-sex friends, they also choose friends with the same character and ideologies, and they talk, hold hands, caress, and kiss and have sexual relationships before marriage according to the religious principles. Most youth choose to study in the general stream instead of the religious one. They spend most of their time with friends, going to movies, listening to songs, going for a ride, playing games, hanging out at night, betting on football, and going to a karaoke places. Most youth do not have a job. Most boys wear T-shirts with pictures on them and shorts while girls wear small-sized hijab, tight skirts, tight T-shirts and tight slacks. Most youth do not have good interaction with their family members and relatives. Most youth do not do anything for charity and do not participate in community activities. Most of them rarely pray five times a day, never fast, never make donations, never read the Koran and never say grace or think of God..." Mrs. Khodiyah (a guardian) emphasized, "...Most Muslim youth have same-sex and opposite-sex friends but their relationships exceed the limits prescribed by Islam. They don't want to study and spend their time uselessly and in a way that violates Islamic principles. They're involved in all vices, and unemployed. They do not dress according to the Islamic principles. They do not have good relationships with family and neighbors. They neglect religious practice and don't like doing charitable activities and don't participate in community 
activities..." Additionally, Mr. Marobee (an academic) gave more details, “...Youth choose to have same-sex friends who don't practice the religion or practice it improperly such as they don't pray or read the Koran, and they don't fast. They drink and take drugs. They go to discothèques, and commit adultery, etc. Youth are alone with their girlfriends or boyfriends. They go out alone teasing and holding hands. Boys ride their motorcycles carrying their girlfriends in the back seat. They don't study in an Islamic school that teaches moral and ethics. They don't study the Koran. They don't study religion and they don't study general subjects. Youth spend time uselessly and in uncreative ways. They don't dress according to the Islamic principles. They don't have good interaction with their family members, relatives, community and neighbors. They're not interested in doing charitable activities".

Therefore, it can be seen that Muslim leaders cannot look after and promote Muslim youth to behave the Islamic way of life and they cannot promote youth to live their life according to the Islamic principles. Moreover, they cannot instill awareness of good things in youth, and cannot teach them right from wrong, and make them feel shame for doing sins through socialization. The socialization process can result in desirable behavior according to religious principles because it can instill in youth discipline, moral and ethics according to social norms (Thitirat, 2004; Sereetrakul, 2009). It can also be seen that the fact that youth do not give importance to studying Islam from their childhood is another factor that make youth live their lives not in accordance with Islamic principles even though all Muslims know very well that studying Islam is their duty. It is important that they have knowledge and understanding Islam and take it as the system of life and practice it as their daily routine. It is said that seeking knowledge of Islam is the duty of all Muslims who must study it completely and correctly in terms of the principles of believe, practice, moral and ethics. They are to take it as the system of life that is prosperous in its growth in knowledge, skill, process, and living in society peacefully and happily (Narongraksakhet, 1997; Mahama, 2009). Studying Islam is important for Muslim youth, and it can prevent youth from all types of problem because knowledge can help prevent them from being lost in the environment and society. Education can make Muslim youth humble and live their lives according to the Islamic principles (Laeheem \& Baka, 2010).

As can be seen from the above research outcomes, Muslim youth nowadays live a very different way of life than before. In the past, most Muslim youth lived a way of life in accordance with expectation of Muslim society and the Islamic principles. Their way of life was with the identity similar to Muslims the world over who strictly practiced their religion in accordance with the guidelines in the Koran and who were modeled after the prophet Muhammad through various ways of teaching and training by different institutions. Nevertheless, presently, only a small proportion of Muslim youth hold this identity while most of them live a way of life that violates the Islamic principles. This serious problem requires all parties concerned to help think and solve the problem. One important cause of the problem is the changing social conditions in technological advancement and the rapid changes in all aspects of the world. This affects the way of life of Muslim youth directly and indirectly causing psychological changes and changes in their living conditions. For example, parents have no time to closely teach and train their children. Youth are not interested in religious activities. Moreover, Muslim leaders neglect social problems and as a result, they become normal happenings. Therefore, Muslim youth live an incorrect way of life. This corresponds with the statements that technological advancements and social change affect the Muslim youth's way of life. For instance, parents have no time for training and teaching their children because they do not have much time together. Youth are so interested in exciting and fun activities that they neglect religious activities but do all vices and use drugs because they are widely available and easy to get. Consequently, Muslim youth deviate from the correct way of life, indulge in the modern way of living, and become slaves to Western values and culture that rapidly come into Muslim society (Anmunajid, 2004; Din-a, 2008; Laeheem \& Baka, 2010). Muslim youth behave in such a way that violates Islamic principles. For example, Muslimah wear hijab but show their shapes. Some Muslim youth use drugs, have problem in their sexual orientation or gender identity, do not pray, cannot read the Koran, have debts, and do not pay Zakat, etc. Moreover, Muslim youth commit sins and taboos so often that they become habits and they do not feel ashamed any longer. They commit sins openly and do religious activities carelessly (Anmunajid, 2004; Mahama, 2009; Laeheem \& Baka, 2010).

\section{Conclusions and Recommendations}

The results of the study show that Muslim leaders have realization and determination in promoting youth to behave according to the Islamic way which is their duty described in the role assigned to them. However, Muslim youth do not give importance and pay attention to activities to promote the Islamic way of behavior that Muslim leaders organize for them. This is because Muslim leaders lack skills, knowledge, understanding of techniques and methods to make the activities interesting, and to use the promotion process that includes youth's participation. The result was that youth do not cooperate and do not participate in the activities. Consequently, 
Muslim youth in Ban Sarong have behaviors that do not meet the expectation of Muslim society and violate the Islamic principles. For example, most Muslim youth have same-sex friends with no limits and with freedom, and they usually do nonsense activities, and make troubles. Some of them have opposite-sex friends openly and freely; they hold hands, caress, kiss and even have premarital sexual relationships. They give more importance to general subjects than religious ones. They do not know how to use their free time usefully. They are engaged in all vices, and unemployed. They dress in a way that makes them look modern like movie stars and singers. Their relationships with their family members and relatives are not very close; they lack good relationships with each other. The relationships with their neighbors and community are not good and they do not pay attention to each other. They neglect and do not give importance to practicing religious activities. They do not give importance to and avoid doing charity and do not participate in community activities. These indicate that nowadays youth have more freedom to live their life and are easily led by fashions, media and peer influence. Because teenagers enjoy things that are new, different and modern, they spend their free time using new technological gadgets, consuming the latest electronic devices, and spending their lives in a modern way.

Therefore, all parties concerned and all levels of organizations in the government and private sectors, parents, guardians and Muslim leaders must have realization, give importance to the abovementioned problems, and join hands to solve them. They must help Muslim youth to live the way of life in accordance with the Islamic principles, especially to promote education that emphasizes both religious and general subjects. They must promote youth to dress according to the Islamic principles, to have friends of the same sex and opposite sex and keep their relations within the limits of the religious principles. They must promote youth to have jobs and occupations, promote them to have good relationships with their family members, relatives, neighbors and community. They must promote youth to learn to sacrifice and do charitable activities. All of these are what Muslim society expects from youth. Muslim leaders and core youth leaders are expected to work together in looking after and promoting behaviors that are in accordance with the Islamic way and meet the needs and interest of youth in the community. All related individuals and organizations should cooperate in the work. Particularly, the government sector should for policy, assign certain organizations to be responsible for the work, provide financial support for youth promotion, support establishments of youth groups or youth clubs in each village to promote and support youth to participate in the operation of looking after and promoting behaviors the Islamic way. The emphasis should be on youth participation in all stages of operation from the thinking process, planning, decision-making, implementing, monitoring and evaluating. Furthermore, all related individuals and organizations should give importance and have realization in seeking ways to help youth to live the way of life designated by Islam, and in preventing youth from living the incorrect way of life according to Islam, and living the way of life that does not meet the expectation of Muslim society.

\section{Acknowledgements}

This work was supported by the Higher Education Research Promotion and National Research University Project of Thailand, Office of the Higher Education Commission.

\section{References}

Anmunajid, S. (2010). Prohibited relationships. Retrieved from http://www.majlis-ilmi.org/islam/modules.php? $\mathrm{op}=$ modload\&name $=$ Sections \& file $=$ index $\&$ req $=$ viewarticle $\&$ artid $=1 \&$ page $=1$

Annadwee, A. (2004). Dear Muslim intellectuals. Retrieved February 19, 2012, from http://www.majlis-ilmi.org/ slam $/$ modules.php?op $=$ modload\&name $=$ Sections\&file $=$ index\&req $=$ viewarticle\&artid $=8 \& p a g e=1$

Baka, D., \& Laeheem, K. (2010). The role of Muslim leaders in educational development of Muslim society in the southern border provinces of Thailand. Songklanakarin Journal of Social Sciences and Humanities, 16(1), 35-51.

Baka, D. (2007). Masjid: Economic basic and cultural capital. Pattani: Prince of Songkla University.

Boonyasith, A. (1988). The role of Islamic leaders in solving the crime problem in the three southern border provinces (Unpublished master's thesis). Srinakharinwirot University, Bangkok, Thailand.

Bureekul, T. (2005). Participation theories and processes. Nonthaburi: King Prajadhipok's Institute.

DeLamater, J. D., \& Myyers, D. J. (2007). Social psychology (6th ed.). Belmont, CA: Tomson/Wadsworth.

Department of Religious Affairs, Ministry of Education. (1999). The manual of Masjid and community managements. Bangkok: Religious Affairs Publishing.

Din-a, A. (2008). The crisis of southern Thailand "It can be solved". Songkhla: Max Media Y2k Press.

Khagphong, P. (2004). Islamic faith on behavior of child breeding of Thai Muslim family in Bangkok 
(Unpublished master's thesis). Prince of Songkla University, Pattani, Thailand.

Laeheem, K., \& Baka, D. (2010). A study of the Thai Muslim youth's way of life to maintaining peace in the three southern border provinces of Thailand. Songklanakarin Journal of Social Sciences and Humanities, 16(6), 973-988.

Laeheem, K., \& Madreh, A. (2014). Youth supervision based on Islam provided by Muslim leaders in southern Thailand. Kasetsart Journal: Social Sciences, 35(1), 92-102.

Laeheem, K. (2012). Youth supervision based on Islamic belief of Muslim leaders in the communities of 3 southern provinces. Kasetsart Journal: Social Sciences, 33(3), 454-463.

Laeheem, K. (2013a). Needs for behavioral refinement based on the Islamic principles among Muslim juveniles with risky behaviors in the three southern-border provinces of Thailand. Kasetsart Journal: Social Sciences, 34(1), 126-138.

Laeheem, K. (2013b). Reception of behavior supervision based on Islamic belief among Muslim adolescents in the three southern-border provinces, Thailand. Kasetsart Journal: Social Sciences, 34(2), 323-334.

Laeheem, K. (2013c). The Islamic way of youth care by Muslim leaders in the three southern-border provinces of Thailand. Asian Social Science, 9(10), 160-168. http://dx.doi.org/10.5539/ass.v9n10p160

Mahama, M. (2009). Islam: Way of life. Songkhla: Po-bard.

Mapobsuk, W. (2000). Human relations. Bangkok: Se-Education.

Narongraksakhet, I. (1997). History of Islamic education. Pattani: Prince of Songkla University.

Patanapongsa, N. (2004). Participation: Basic principles, techniques and case studies. Chiang Mai: Chiang Mai University.

Prachantawanich, A. (2007). Causal relationships of work environment factors and personal factors related to personal participation in Thammasat University's education quality assurance (Unpublished master's thesis). Srinakharinwirot University, Bangkok, Thailand.

Satsangan, N. (2000). The principle of cultural anthropology (4th ed.). Bangkok: Rama Printing.

Sengpracha, N. (1994). Manual of community development. Bangkok: Rungsin Printing.

Sengpracha, N. (1998). Human and society (4th ed.). Bangkok: O. S. Printing House.

Sereetrakul, W. (2009). Factors affecting family solidarity in the opinions of Thai teenagers (Unpublished master's thesis). Ramkhamhaeng University, Bangkok, Thailand.

Spector, E. (2006). Industrial organizational psychology: Research and practice (4th ed.). New York: Willey.

Srimechai, N. (2004). Factors affecting adult learners' participation in vocational short courses in non-formal education centers in Bangkok metropolis (Unpublished master's thesis). Chulalongkorn University, Bangkok, Thailand.

Suphap, S. (2003). Sociology (23rd ed.). Bangkok: Thai WatanaPanich.

Suratanakawikul, P. (1999). Human and society (2nd ed.). Bangkok: Kasetsart University.

Tahe, H., \& Laeheem, K. (2013). The causes of reduction of the role in youth management according to the Islamic way among Muslim leaders in the three southern border provinces. Asian Social Sciences, 9(17), 135-143. http://dx.doi.org/10.5539/ass.v9n17p135

Tansakul, P. (2004). Why teams do not work. Bangkok: Jit Jakawarn.

Thitirat, P. (2004). Human and society. Bangkok: Kasetsart University.

\section{Copyrights}

Copyright for this article is retained by the author(s), with first publication rights granted to the journal.

This is an open-access article distributed under the terms and conditions of the Creative Commons Attribution license (http://creativecommons.org/licenses/by/3.0/). 